\title{
Assessment of Experiential Learning and Teaching Approaches in Undergraduate Programmes at the School of Agricultural Sciences, Makerere University, Uganda
}

\author{
Opolot Henry Nakelet ${ }^{1}$, Isubikalu Prossy ${ }^{1}(\mathrm{PhD})$, Obaa Bonton Bernard ${ }^{1}(\mathrm{PhD})$, Ebanyat Peter $^{1}(\mathrm{PhD}) \&$ Okello \\ Dorothy $^{2}(\mathrm{PhD})$ \\ ${ }^{1}$ School of Agricultural Sciences, Makerere University, P.O Box 7062 Kampala- Uganda \\ ${ }^{2}$ College of Engineering, Design, Art and Technology (CEDAT), Makerere University, P.O. Box 7062, Kampala- \\ Uganda.
}

Correspondence: Opolot Henry Nakelet, School of Agricultural Sciences, Makerere University, P.O Box 7062 Kampala- Uganda

Received: September 22, 2017

Accepted: October 22, 2017

Online Published: October 23, 2017

doi:10.5430/ijhe.v6n5p155

URL: https://doi.org/10.5430/ijhe.v6n5p155

\begin{abstract}
Competent graduates are a critical input in enhancing the university's role in agricultural transformation. How graduates play their role in contributing to development mirrors on how they trained. Low quality graduates are believed to be a product of a more subject-centered and instructive style of teaching. The Makerere University Kampala School of Agricultural Sciences (SAS) made effort to improve and enhance the competence of its lecturers to use a learner centered teaching approach in its programmes through training. This paper presents an assessment of how the training influenced the lecturers to use different teaching practices toward producing quality responsive graduates. Data was collected from 120 students and 20 lectures from the SAS using a semi-structured questionnaire. The findings show that Training lecturers in experiential learning influenced their awareness and use of experiential learning approaches in delivery of the courses they taught. Effective application of experiential learning approaches was constrained by challenges of varied understanding and appreciation of the concept among lecturers, short class periods, large class sizes and financial limitations. In effect, the traditional lecture method remained dominant. Above all, application of experiential learning approaches is not institutionalized at SAS thus limiting the attainment of critical and reflective thinking for the attainment of lifelong learning abilities among students. To strengthen application of experiential learning approaches, training of all lecturers and curriculum review to integrate experiential learning practices as part of the general teaching quality assurance measures is critical.
\end{abstract}

Keywords: Makerere University, Experiential learning, Student-centered learning, Curriculum, Responsiveness, Institutionalization

\section{Introduction}

Universities have the responsibility to produce graduates with competences to facilitate development in general. Graduates from agricultural-based universities in this case have the responsibility of driving agricultural and rural transformation. Agriculture is largely a rural phenomenon and remains a major livelihood source especially in developing countries (Mugisha and Nkwasibwe, 2014; World Bank, 2012) where more than $80 \%$ of the subsistence based population dominate the industry. Overtime, tracer studies have indicated that students from agricultural institutions of higher education graduate with excellent academic grades but exhibit limited impact in influencing development in society (Mugisha and Nkwasibwe, 2014). Limited impact or inability of graduates to influence development processes has partly been attributed to the dominant and often one way conventional lecture approach (largely using chalk-board technology) used in many universities (Driscoll, 2011; Baenten et al., 2010). The one direction lecturer-centred mode of instruction, where learners are perceived to be passive recipients of knowledge from lecturers (Driscoll, 2011; Wurdinger and Rudolph, 2009) does not allow learners to make use of and create meaning from experience. This shows that the teaching at university promotes more of the cognitive level than enhancing the psychomotor and effective learning.

Looking at the six sub-levels in the cognitive hierarchy (knowledge, comprehension, application, analysis, synthesis and evaluation) of Bloom's domains of learning (Bloom et al., 1971), the lecturer-centred approach focuses on the 
learners' ability to recall (knowledge) and expression of basic understanding (comprehension) of what is learnt. This way of learning limits the learner's ability to apply acquired knowledge (theory/content) to other situations. Learning is an active process that should go beyond knowledge and comprehension. Limiting the learning to the first simple sub-levels of the cognitive domain does not encourage development of skills or permit graduates to use or translate what they know to solve problems they find in the work places. This could explain why most graduates are said be competent technically but are lacking in social skills which play a big role in making the technical skills useful to communities (Aspin et al., 2012; Caprara et al., 2011; Eyler, 2009; Kibwika, 2006). The competence of graduates in addressing development challenges is one key measure of the university training process that is responsive to real development needs and thus critical in strengthening University-Community Engagement - one of the tripartite functions of universities (Mugabi, 2015; Owusu-Acheampong et al, 2014; Sunmonu and Tijani, 2013; YU, 2013).

In spite of the existence and importance of student-centred teaching methods/approaches, their use is limited. Ueckert et al. (2011) and Twenge (2009) observe little progress in applying the methods especially among institutions of higher learning in developing countries. The lecture method remains the most dominantly used mode of teaching (Slavich and Zimbardo, 2012), making the universities to appear rigid in this context. Different factors could explain the rigidity in the use of available student/learners centred methods mentioned above. Some of the factors perceived to influence application of these approaches are said to revolve around the universities' institutional and structural environment, students' characteristics, nature of courses offered and, the technical capacity and orientation of the lectures (Baeten et al., 2010; Diseth et al., 2010; Kember et al., 2008).

In a study conducted by Kibwika (2006) on 'developing innovation competence for recreating the African university of the 21 st century' in Makerere University, the need to re-orient lecturers to be in a better position to train students using improved methods was found to be very important. The focus was largely on social competences. His argument was that social skills are the skills that enhance communicative, interactive and facilitative abilities of a person to influence change in society. To be able to engage students to have interest in the content and process requires social competences. While learning through experience is not a new idea, very few lecturers are trained or exposed to teach in different ways other than the lecture method (NIU, 2013; Wurdinger and Rudolph, 2009). This could be because the lecturers were exposed to and only knew the lecture method or it is the method they are comfortable with. Students perceived to be brighter than the rest as reflected in their academic performance are the pool from which potential lecturers are drawn. Learners tend to copy exactly what their instructors do, in most cases. Focus on the lecture method as used by professors limits the exposure and consequently knowledge and attempts of using different ways of teaching. As a result, the system of looking at and using the lecture as the sole teaching method gets perpetuated through generations. Lecturers in most cases are not trained to be teachers. Evidence of teaching ability is seldom a requirement for recruitment of lecturers unless in very special circumstances when an applicant is from outside Makerere University (Ezati et al., 2014). In education related university programmes, students are trained to be teachers, but these students rarely get an opportunity to be recruited in agricultural sciences related university programmes. The recruiting style of retaining those with the best grades assumes that they know what and how to teach. Similarly, promoting lecturers through the ladders to professorship uses the number of years in service as one of the basis to assume that the person should have gained pedagogical competences (MAK, 2014). Such lecturers are in a way expected to impart all round skills to students but Kibwika (2006) questions their ability to do so when they themselves are lacking the practical competences.

At Makerere University, save for the positions of Professor, evidence of pedagogical skills is not an explicit requirement for one to be employed from the position of Teaching Assistant to Senior Lecturer (MAK, 2013; 2012). This is why upskilling lecturers in new teaching methods responsive to development challenges is important (Kibwika, 2006). For that reason, between 2007 and 2009 Makerere University conducted a series of curriculum and pedagogical workshops meant to expose some lecturers to pedagogical skills as a mechanism to upskill the lecturers and improve the quality of teaching (Ezati et al., 2014). Focus was on the different interactive learner-centred teaching methods that included personal mastery (Hawkins, 2010) to stimulate reflective teaching. Promoting a holistic learning and applicable research requires university staff to apply critical and reflective teaching approaches. To achieve this, calls for enhancing capacity of lecturers in application of experiential learning approaches.

\subsection{Context of the Study}

Experiential learning is understood, conceptualised and used differently by both lecturers and students in institutions of higher learning. For example, varied levels of understanding the concept within agricultural faculties was demonstrated in the gap analysis study that Hawkins (2010) conducted in the Universities of Makerere in Uganda, Moi in Kenya and Bunda in Malawi,. The implication is lack of uniformity in teaching methods. Some lecturers 
largely use the traditional lecture approach while others try to integrate some aspects of participatory methods in teaching. This also affects the quality of graduates produced as many will be equally deficient in soft skills. The recommendation to address this anomaly was to provide training so as to bring understanding and application of this concept among lecturers to the same level.

Under a European Union funded regional project titled "Shifting from outreach to engagement: Transforming universities' response to current development trends in agricultural research and training" through the Regional Universities Forum for Capacity Building in Agriculture (RUFORUM), academic staff from agricultural faculties in the three universities of Makerere, Moi and Bunda were subjected to a series of training workshops aimed at strengthening their competences in interactive and experiential learning approaches. In the Makerere University School of Agricultural Sciences (SAS) 15 lecturers selected from the five departments of SAS were trained. The project aimed at promoting lecturers' understanding and application of the experiential learning approaches so as to make research, teaching and outreach practices in university training responsive to community needs. Topics covered included experiential learning, curriculum development, integrating experiential learning into curricula, integrating soft skills into academic programmes and maximising experiential learning in the classroom (Hawkins and Lokopoit, 2012). The training allowed lecturers to conceptualise and practice what they learnt through role plays, group work, discussions and, action planning, making it easy for them to use the methods in their different contexts. The selection of the lecturers for the training was based on individual expression of interest to learn and try the concepts; association with a course whose delivery calls for more practical and interactive sessions to make the students easily understand the content and be interested; and with possibility of continuing to serve at the university in the next 10-15 years.

The Earth University in Costa Rica and Land-Grant Universities in USA are credited for effective implementation of innovative learner-centered academic programmes in agricultural training. Training in these models emphasizes both the application of experiential teaching and learning approaches. The focus is on getting students to learn more by exposure to and undertaking of, real practical activities in farms and laboratories throughout the academic course duration. These universities follow a student-centered educational process which according to Hawkins (2010) instill in students the proper attitudes to become effective agents of change. Experiential learning is therefore entrenched in these models and hence the curricula have a strong balance between imparting technical and social skills with a commitment to life-long learning. To enable application of experiential learning, the lecturers in these universities are continuously trained and accustomed to the practice. It is the continuous competence developed among both lecturers and students that enhances the university's responsiveness to real-life problems. According to Damian et al. (2007), emphasis in experiential learning through practice than classroom alone, enhances learning by making observations and relating lessons to the abstract disciplinary knowledge found in the classroom. A special call is indeed made for undergraduate students to experience interdisciplinary learning that is inquiry-based and socially engaged (ibid).

The pressure on developing country universities to produce competent graduates to support establishments of sustainable agro-food value chains is on-going (Obaa, 2013; MAK, 2006). There is thus, need to upscale application of interactive and experiential-based teaching approaches that enhances the usefulness of university graduates. Makerere University and SAS in particular, made efforts to re-orient lecturers in pedagogical, learner-centred experiential learning methods in a bid to enhance the responsiveness of university graduates to the productive needs and job market requirements of the agricultural sector. However, there has been no follow-up to find out how the lecturers and students are responding to the seemingly new or improved style of teaching. It is not clear if the experiential learning training improved the teaching and consequently the quality of graduates as was conceived. Whether the lecturers are equally using the experiential methods in their lecture delivery at SAS is not known. Information on how the training has influenced the teaching methods at SAS is unavailable. This point to one central research question that guided this study, "In what ways did the training in experiential learning approaches influence the lecture delivery methods aimed at producing the desired responsive graduates at SAS?"

The focus of this paper is establishing the perspective of students and lecturers on the application of experiential learning approaches at SAS, and exploring the implications for improving the quality of graduates. Lecturers in this context refer to those who underwent the training on experiential learning and action research facilitated by RUFORUM. Participants in the study were undergraduate students who are often thought to join university with a perception of the teacher as the provider and source of knowledge (Acayo, 2013). It is important to know how the university students actually perceive the interactive teaching style the lecturers introduce and how these styles stimulate their interest in the content taught. 


\subsection{Analytical Framework}

Experiential learning theory (ELT) (Kolb, 1984) provided the most appropriate analytical framework for the study. Effective teaching methods should integrate activity-based approaches meant to provide opportunity for students to be more actively engaged in their learning. Characteristically, the approaches according to Baeten et al. (2010) and O'Neill and McMahon (2005), should involve activities that enhance students' independence while positioning the lecturer as a facilitator as well as co-learner. A diverse array of activities to aid deeper learning can take place both in and out of the classroom setting, although Svinvki and Mckechie (2011) prefer the application of activities outside the classroom. It does not however imply that the lecture method is avoided altogether but preferably it comes with some engaging and reflective activities to clarify meaning and/or content (Barraket, 2007). The key identifier of experiential leaning (Bartle, 2015; Fry et al., 2009), is the effort to have students continuously evaluate their own learning progress through constant reflection. Focusing on the factors limiting the application of experiential learning, the impact of their integration can be determined through the learners perspective of the quality of teaching and teaching methods used. Research reports that integration of experiential learning is among others symbolized by participatory teaching methods; reduced dominance of the lecturer; relevance of course material; the extent of self-learning and evaluation by students (Bartle, 2015; NIU, 2013; Baeten et al., 2010).

\section{Research Methodology}

The research design was a single case study undertaken in the School of Agricultural Sciences (SAS), Makerere University. This was to facilitate an empirical inquiry and rich description (Rolf, 2007; Yin, 2006) of students and lecturer' perspectives in regard to the application of the experiential learning approaches. SAS is one of the units in Makerere University where some lecturers underwent training on experiential learning with the objective of improving teaching styles. Although the lecturers taught both undergraduate and postgraduate levels, the study focused only on the undergraduate level. Graduates at this level are the ones who get to work directly with farming communities in the field. Undergraduate students enrolled in the three of the five programmes of SAS with larger enrolments formed a representative sampling pool. These were B.Sc. Agriculture (AGRIC), Bachelor of Agribusiness Management (AGM) and, Bachelor of Agricultural and Rural Innovations (BARI). Fifteen lecturers from the three SAS departments Agricultural Production, Extension and Innovation Studies and, Agribusiness and Natural Resource Economics who attended the RUFORUM supported experiential learning training were selected for the study.

For impact attribution purposes, on a ratio of 1:1(Austin, 2010), 15 SAS lecturers who did not attend the RUFORUM training but who taught courses to classes that the trained lecturers taught too, were targeted for the study. To verify the teaching approaches used by lecturers and the levels of learner satisfaction with the quality of teaching, undergraduate students enrolled in one course unit taught by a 'trained' lecturer and one (1) course unit taught by a 'non-trained' lecturer during the first semester of the 2014/15 academic year were considered for the study. A total of 170 students were sampled based on class size using Slovin's formula $n=N /\left(1+\mathrm{Ne}^{2}\right)$ for the study where $n=$ sample size; $\mathrm{N}=$ total population and $\mathrm{e}=$ desired error of margin (0.05). The sampling was purposive considering the semi-finalists and final year students from three SAS programmes of SAS (AGRIC III \& IV; AGM II \& III and; BARI II). BARI III was not considered for the study since no course unit taught by any 'trained' lecturer was offered at the time of the study.

The target number of respondents was 200 comprising 30 lecturers and 170 students. A self-administered semi-structured questionnaire was used to capture the responses. The respondents who returned the questionnaires were 122 students and 20 lecturers giving a response rate of $72 \%$ and $60 \%$, respectively. To determine the students' opinion on the quality of teaching by the two categories of lecturers, a five - point Likert scale was used for students to indicate their level of agreement or disagreement with the given statements with score $1=$ Strong agreement, $2=$ Agreement, 3 = No opinion, $4=$ Disagreement and,5= Strong disagreement. A mean score closer to one (1) indicated a positive agreement with the statement. The statements used in the questionnaire were paraphrased from Bartle (2015); NIU (2013); and Baeten et al. (2010) on assessing integration of experiential learning. Students were asked for example, if the lecturer: uses participatory approaches, is less dominating; uses up to-date teaching materials; encourages individual learning, research and reflection. The Qualitative data from students and lecturers' questionnaires was analyzed using thematic content analysis (Hsieh-Fang and Shannon, 2005) to generate themes relevant to the aims of the study. Quantitative data from the students' questionnaires was coded and analyzed using the SPSS version 18 to generate descriptive statistics (means and frequencies) of the perceptions on teaching approaches. Independent sample T-test was used to determine the difference or lack of it in the perceived quality of teaching by the two categories of lecturers. 


\section{Results and Discussion}

\subsection{Profile of Respondents}

The majority of students interviewed (87\%) were aged 23 years on average with no female aged above 30 years. The direct entry students were the majority interviewed as is the most popular way students get admitted to the university with a few opportunities for diploma and mature age entry schemes. The majority of students interviewed were privately sponsored which conforms with the 30:70 of government to private sponsored students in Makerere University. A total of 20 SAS lecturers were interviewed $60 \%$ of whom had attended the RUFORUM supported experiential learning (EL) training workshop. While the research design was to match trained lecturers and non-trained lecturers, over $60 \%$ of the lecturers interviewed had attended an experiential learning related training conducted/supported by organizations other than RUFORUM and others in the course of their professional training. Considering both the RUFORUM trained lecturers and those trained elsewhere, only $20 \%$ of the lecturers interviewed did not have any exposure to experiential learning training and this may have a bearing on the results of the study. More than half of the lecturers interviewed were from the Extension and Innovation Studies Department on account that they formed majority of the RUFORUM - EL training participants.

Most of the lecturers interviewed (90\%) were below 50 years of age with over $70 \%$ being PhD holders. Over $60 \%$ of those interviewed were the mid-career professionals, namely Lecturers and Senior Lecturers. The age bracket of those interviewed was equally pre-determined by the same parameters of those who attended the RUFORUM-EL training. As for the students, the total response was influenced by availability and willingness to respond with the RUFORUM-EL trained lecturers having higher response than others.

\subsection{Teaching and Learning Approaches Used by Trained and Non-trained Lecturers at SAS}

Students listed the teaching approaches used in two different course units each taught by a RUFORUM-EL trained Lecturer and a non RUFORUM-EL trained lecturer, respectively, while lecturers were asked to name in general the teaching approaches they use in delivering assigned course units. Table 1 shows the non-parametric analysis of the teaching approaches used by the two categories of lecturers as mentioned by students.

Table 1. Teaching approaches used at SAS as mentioned by students

\begin{tabular}{llllll}
\hline $\begin{array}{l}\text { Teaching } \\
\text { Approach }\end{array}$ & Training & $\begin{array}{l}\text { Responses } \\
\mathbf{( N = 1 2 2}\end{array}$ & $\begin{array}{l}\text { Observed } \\
\text { proportion }\end{array}$ & $\begin{array}{l}\text { Test } \\
\text { Proportion }\end{array}$ & Significance \\
\hline Power point & Trained & 28 & 0.47 & 0.50 & 0.795 \\
& Non-Trained & 31 & 0.53 & & \\
Group Discussion & Trained & 28 & 0.57 & 0.50 & 0.392 \\
& Non-Trained & 21 & 0.43 & & \\
Individual & Trained & 15 & 0.65 & 0.50 & 0.210 \\
assignment & Non-Trained & 8 & 0.35 & & \\
Interactive & Trained & 59 & 0.63 & 0.50 & $0.012^{* *}$ \\
Lectures & Non-Trained & 34 & 0.37 & & \\
Lectures & Trained & 74 & 0.53 & 0.50 & 0.575 \\
& Non-Trained & 82 & 0.47 & & \\
Practical field trips & Trained & 39 & 0.56 & 0.50 & 0.403 \\
& Non-Trained & 31 & 0.44 & & \\
Reflection & Trained & 6 & 0.67 & 0.50 & 0.508 \\
& Non-Trained & 3 & 0.33 & & \\
\hline
\end{tabular}

**Significant and 5\% level

The Binomial test procedure (Smits and Rossi, 2005) was used to compare the observed proportion of the two categories of a dichotomous variable to the proportion that is expected under a binomial distribution with a 0.50 probability parameter. The analysis tests whether the observed proportion of the teaching approaches between the trained and non-trained lecturers is different from the 0.5 test proportion. Overall, the students scored lecture approach (82 \& 74), interactive lecture (including question and answer sessions, brainstorming; 59 \& 34), and 
practical work (field trips, demonstrations and laboratory practicals; $39 \& 31$ ) as the most dominant approaches used by the trained and non-trained lecturers respectively. Power point presentations were listed as a teaching approach as students found them easy to follow what is being taught. The approaches used to a lesser extent were reflection/case study (6 \& 3), individual assignments (15 \& 8) and group work (group discussion, assignments and presentation; 28 \& 21). Generally, the binomial test statistics showed no evidence that there was a significant difference in the observed proportion in the group discussion, individual assignment, lectures, practical field trips and reflection teaching approaches teaching approaches reported between the trained and non-trained lecturers. However, there is strong evidence that the observed proportion for the teaching approach interactive lectures was significantly different $(\mathrm{p}<0.5)$ between the trained (63\%) and non-trained (37\%) lecturers. The trained lecturers used more interactive and practical approaches than the non-trained lecturers.

During the interviews, those who had not attended any additional training mentioned fewer teaching approaches on account of limited exposure as one stated: "I am yet to be exposed to any kind of experiential learning to understand the different teaching and learning approaches" (Lecturer, May 2015). The teaching approaches the lecturers interviewed mentioned to be using take the exact trend as those listed by students as follows: lectures (85\%), interactive lectures (39\%), practical work (35\%), power point (29\%), group discussion (24\%), individual assignment $(11 \%)$ and, reflection (5\%). The results on approaches used by lecturers could not be disaggregated by trained and non-trained since almost all those interviewed excluding four, had exposure to experiential leaning.

The findings show that whilst there are several teaching approaches being used at SAS and other universities, the lecture method is still dominant (Slavich and Zimbardo, 2012; Twenge, 2009). The dominance of the lecture method may not necessarily mean a total lack of application of experiential learning approaches. While the study did not delve into the structure of the 'lecturing', Barracket (2007) opines that the lecture method ought to be de-emphasized and largely used to clarify content. As an indication of formal lecture modification, the low application of in-class reflection activities, individual assignments and group work, the traditional lecture approach remains dominant. Despite this, the training in experiential learning is important as it encourages lecturers to make students participate in their learning. Arnold and Paulus (2010) noted that less structured lectures stimulate more conversation and reflection, and calls for increased training or exposure of lecturers to student-centered teaching methods so as to improve the quality of learning.

\subsection{Students' Rating and Preferences for Teaching Approaches}

Students were asked to rank the teaching approaches they were exposed to with reasons for preference. Table 2 shows that students preferred participatory approaches that reduced the gap between the lecturer and students. Interactive lectures $(60.5 \%)$ and practical sessions $(51.9 \%)$ were most preferred while reflective sessions and individual assignments were least preferred. Research by Haak et al. (2011; Svinvki and McKechie, 2011) affirm the importance of interactive classes and activity based/practical learning for improved educational outcomes. The practical sessions enhanced students' learning and understanding of content but required more time. This was contradictory to students claiming they were not willing to stay in class beyond the timetabled period. The lecture method ranked equally high $(43.2 \%)$ in the students' preference for the introduction and clarification of new concepts, theories or experiences (Pantiru et al, 2012) and elicited the most dislikes for not encouraging participatory and individual deep learning. 
Table 2. Rating of teaching approaches by SAS students $(\mathrm{n}=122)$

\begin{tabular}{|c|c|c|c|c|}
\hline Approach & $\begin{array}{l}\text { Preference } \\
\text { rating }(\%)\end{array}$ & Ranking & Reasons for preference & Reason for dislike \\
\hline $\begin{array}{l}\text { Interactive } \\
\text { lectures }\end{array}$ & 60.5 & 1 & $\begin{array}{l}\text { There is more active learning; } \\
\text { sharing of ideas; interaction with } \\
\text { the lecturer and; gets one out of the } \\
\text { 'comfort zone' }\end{array}$ & It is time consuming \\
\hline $\begin{array}{l}\text { Practical } \\
\text { work/field } \\
\text { trips }\end{array}$ & 51.9 & 2 & $\begin{array}{l}\text { Makes it easy to relate theory to } \\
\text { reality and thus increased } \\
\text { understanding hence one sees, hears } \\
\text { and does practically. }\end{array}$ & Takes much time \\
\hline Lectures & 48.1 & 3 & $\begin{array}{l}\text { Enables a lecturer to cover more } \\
\text { content; enables understanding of } \\
\text { new concepts or theories and } \\
\text { clarification of the subject. }\end{array}$ & $\begin{array}{l}\text { Limits participation, encourages } \\
\text { cram work, can get boring and hard } \\
\text { to sustain attention depending on } \\
\text { the lecturer's character }\end{array}$ \\
\hline Power point & 43.2 & 4 & $\begin{array}{l}\text { Helps focus attention as one follows } \\
\text { what the lecturer says and makes } \\
\text { understanding }\end{array}$ & $\begin{array}{l}\text { Some may have crowded slides or } \\
\text { small letter font }\end{array}$ \\
\hline Group work & 24.7 & 5 & $\begin{array}{l}\text { Allows sharing of ideas; improves } \\
\text { communication skills and builds } \\
\text { confidence through presentations }\end{array}$ & $\begin{array}{l}\text { Encourages others to 'hide' without } \\
\text { contributing to group work ('free } \\
\text { riders'); requires time }\end{array}$ \\
\hline $\begin{array}{l}\text { Individual } \\
\text { assignments }\end{array}$ & 12.3 & 6 & $\begin{array}{l}\text { Encourages self-learning though } \\
\text { own research and associating with } \\
\text { others while seeking support }\end{array}$ & $\begin{array}{l}\text { Difficult to access reading } \\
\text { materials, sometimes done to } \\
\text { complete but not understanding the } \\
\text { assignment }\end{array}$ \\
\hline $\begin{array}{l}\text { Reflection } \\
\text { sessions }\end{array}$ & 1.2 & 7 & $\begin{array}{l}\text { Encourages more active learning } \\
\text { using practical examples }\end{array}$ & Takes much time \\
\hline
\end{tabular}

While students approve of group work (24.7\%) as an approach that enhanced the development of personal relations skills and confidence, they also considered consuming if not well facilitated, with the possibility of a few group members completing much work with little or no contribution by other group members. Individual assignments and reflection sessions which enhance self-learning, research abilities and critical reflection were somehow dreaded by students. This is for reasons including challenges in accessing literature as a result of poor internet connectivity, low accessibility to library resources and case study material, due to limited knowledge or laziness. Experiential learning places responsibility for learning solely with the learner, but as Prince and Felder (2006) observed, some students may not intentionally or otherwise be up to the task of critical thinking and reflection. For this reason, approaches requiring individual study, critical thinking and reflection score low. With the capacity to facilitate experiential learning however, NIU (2013), Eyler (2009) and Justine et al. (2007) stress the need to ensure students develop capacity for lifelong learning. This gives more impetus to the need for capacity building of lectures as facilitators of learning and institutionalization of the practice so it becomes formally integrated in academic programmes to enhance production of competent graduates.

\subsection{Lecturers' Opinion on Usefulness of the Training in Experiential Learning}

The lecturers trained in experiential learning approaches in both RUFORUM-EL training or others were asked to describe whether the training was beneficial to them. All the trained respondents highlighted numerous benefits of the training especially in adapting to student-centered learning approaches. The key lessons taken from the training were that applying active learner-oriented strategies (53.8\%) creates a deep engagement with students (69.2\%). Such a defining statement from one of the respondents was that 'to effectively teach science courses require use of activity-based, student-centered teaching approaches' (May 2015, Lecturer). Additionally, complicated concepts are best taught through the use of a variety of teaching methods (46.2\%) other than the conventional lecture approach with limited participatory learning. Creating interaction with students and positively receiving feed-back (38.5\%) was another lesson taken by the lecturers from the training. Respondents were unanimous in stating that 'students should be fully involved in the learning experience through effective communication, creating a relationship between 
learner to self, learner to lecturer and learner to environment' (May 2015, Lecturers). Another more critical element was the need to re-orient the role of a lecturer to facilitating learning as one said; 'as a lecturer, I was able to revisit my own pedagogical philosophy and methods to ensure facilitation of active learning in a safe space allowing for self-exploration and discovery' (May 2015, Lecturer).

On application of lessons learnt to improve the teaching and learning of the students, there mixed reactions. The newly applied approaches revolved around trying to make classroom teaching more interactive, improving the use of power point presentation by including pictures and showing videos and promoting reflection through use of case studies. What was imperative to note was their observation of the students' response to the use of experiential learning approaches. The students appreciated the participatory and practical teaching approaches that improved understanding of subject matter as some lecturers stated; 'some students have confessed that interactive teaching approaches have simplified previously hard-sounding aspects of the course $(24 \%)$ and the level of attendance and focus $(26 \%)$ greatly improved'. It has also enhanced students' ability for independent study (18\%), and respondents also observed that some students felt it results in a lot of work for them $(29 \%)$.

The findings in this section, show the importance of training in experiential learning to the lecturers. All lecturers who had participated in the experiential learning training expressed an understanding of how these approaches promote deeper and two way learning. Whilst the majority of lecturer respondents $(70 \%)$ held a $\mathrm{PhD}$, they often continued to teach the way they were taught because pedagogical courses were neither integrated in the doctoral programmes nor a recruitment requirement to teach at the university (Ezati et al., 2014; Wurwinger and Rudolph, 2009). The understanding of lecturers to the value of experiential learning training is supported by the many lessons said to be learnt and the positive reaction of students. It appears that the training promoted change in lecturer practice to use student-centered learning approaches. This comes with new demands for lecturers to adequately prepare in order not only to make learning participatory but to keep it brief and interesting within the allotted time. There has to be increased interest in reading to discover new information to ensure information presented is always up-to-date. A close relationship between lecturers and students has to be built to promote social and academic guidance to students. Looking at avenues for reviewing curricula to enhance more experiential learning is a critical issue here.

\subsection{Students' Assessment of the Training Methods by Trained and Non-trained Lecturers}

To further interrogate the value and application of experiential leaning approaches, the study sought students' opinions on the teaching practices of the two categories of lecturers Table 3 reports an independent T-test of the mean differences of the students' assessment of the quality of teaching by the two categories of lecturers based on a 5-point Likert-scale. Overall, the mean scores for the assessment of teaching by two categories of lecturers shows agreements with the statements (mean scores < 3) except for the statement of dominating tendency of the non-RUFORUM trained lecturers (mean score $>3$ ). The mean scores for the trained lecturers were generally lower than for the non-trained lecturers that were tending towards dissatisfaction (mean score close to or above 3) across the statements. This probably indicates that the training to an extent enhanced the use of experiential learning approaches and hence beneficial. Among the trained lecturers, students agreed more strongly with the participatory approach the lectures (Mean $=1.92$ ) followed by the use of relevant teaching materials (Mean $=2.17$ ). For the case of the non-trained lectures, students agreed more with the use of relevant materials (Mean $=2.40$ ) followed by the participatory teaching approaches (2.43). This probably implies that the training helped lecturers to make learning more participatory beyond just having relevant materials. Making learning participatory is said to make learners co-creators of knowledge and learning materials (Driscoll, 2011). In essence, promoting participation in learning appeared a key benefit of the training. 
Table 3. Mean differences and T-Statistics on students assessment of the teaching practices by the RUFORUM-EL trained and non-trained SAS lecturers $(\mathrm{n}=122)$

\begin{tabular}{lllll}
\hline Statement on level of satisfaction & $\mathbf{M}^{\mathbf{1}}$ & $\mathbf{M}^{\mathbf{2}}$ & $\mathbf{S D}$ & $\mathbf{T}$ - Value* \\
\hline Lecturer uses participatory teaching approaches & 1.92 & 2.43 & 1.14 & $-3.308^{* * *}$ \\
Lecturer is less dominating & 2.73 & 3.08 & 1.17 & -1.518 \\
Lecturer uses up to date teaching materials & 2.17 & 2.40 & 0.92 & -1.738 \\
Students have input in the learning process & 2.45 & 2.83 & 1.04 & $-2.729^{* *}$ \\
Students are encouraged to do own research & 2.46 & 2.85 & 4.08 & 0.477 \\
Students do self-evaluation and reflection & 2.61 & 2.85 & 1.19 & -1.448
\end{tabular}

$\mathrm{M}^{1}=$ Mean score for RUFORUM-EL Trained Lecturers (Treated); $\mathrm{M}^{2}=$ Mean score for non-RUFORUM Trained Lecturers (Control); $\mathrm{SD}=$ Standard Deviation; *Equal variances assumed; **p $<0.01, * * * \mathrm{p}<0.001$

Across the two categories of lectures, students agreed least with the statement of 'less dominating' practices of the lecturer during lectures. In comparing the teaching approaches for the two categories of lecturers, there was no statistically significant deference $(\mathrm{p}<0.05)$ for all the statements except two. The difference between the mean scores of the trained and non-trained lecturers teaching approaches is statistically significant in the use of participatory teaching $(\mathrm{p}<0.001)$ and having students make input in the learning process $(\mathrm{p}<0.01)$. It thus appears that experiential learning training made a difference in the way lectures were delivered. Whilst the majority lectures were exposed to experiential learning through various sources, it occurs that continuous training could bring about new improvements each time.

To interrogate further if training can create a difference in the quality of teaching, the lecturers sampled were asked if it was important to have all lecturers trained in the use of experiential learning approaches. There was approval of the need to have all lectures equipped with student-centered teaching skills. Respondents (95\%) believed that there was a need to use more interactive student-centered approaches to ensure effective learning than the traditional (lecture) approach. This is emphasized by some respondents who stated that most university lecturers have not gone through education/teaching courses and are therefore not trained to be (effective) teachers. One of the lecturers who was not exposed to any additional experiential learning training felt ill-equipped to teach saying "I rely on my own experience. I mastered the approaches in which I was taught as a former student to maximize learning" (May 2015, Lecturer).

Universities recruit graduates with excellent grades as lecturers but without initial pedagogical training, and as Ezati et al. (2014) observed, they will teach the way they were taught. Learning through experience seldom guarantees application of the desired teaching approaches. As Slavich and Zimbardo (2012), Aspin et al. (2012); Caprara et al. (2011) state, when experiential learning approaches are applied, positive approval of lecturers by students becomes evident through increased class attendance, persistence and more engagement with course content as self-reported by the lecturers. It is therefore important that lecturers once recruited should be taken through experiential training so as to orient them towards learner-centered teaching in order to facilitate desired competence acquisition among students. More needs to be done to validate the deeper impact of the application of experiential learning approaches specifically, exploring the relationship between the application of experiential learning and the development of critical analytical skills by the students.

\subsection{Challenges to Better Application of Experiential Learning Approaches at SAS}

The findings report that both students and lecturers appreciate the need for application of experiential learning approaches. However, interest and efforts to apply the same at SAS notwithstanding the lecturers interviewed explained that there are a number of challenges that influence the extent to which experiential learning approaches can be integrated. The challenges enumerated by the respondents in relation to the different learning and teaching approaches are presented in Table 4. 
Table 4. Challenges to application of experiential learning approaches as expressed by SAS lecturers

\begin{tabular}{ll}
\hline Approach & Descriptors of challenges faced \\
\hline Group work & $\begin{array}{l}\text { Limited space for large classes; requires a lot of time prepare; low availability of } \\
\text { materials to use; poor attitude of some students to group work. }\end{array}$ \\
Individual assignments & $\begin{array}{l}\text { Poor internet connectivity for individual research, poor reading culture and low } \\
\text { knowledge on use of online resources. Limited commitment to preparation. It needs } \\
\text { time to know what the assignment is about and how it will flow. Some students do } \\
\text { not like criticism. }\end{array}$ \\
Needs a lot of time; low interest in in-depth learning by students; limited capacity of \\
Interactive lectures & $\begin{array}{l}\text { lecturers to facilitate participatory learning - some people still want to show that } \\
\text { they are the most knowledgeable in specific fields; some students do not like } \\
\text { criticism }\end{array}$ \\
& $\begin{array}{l}\text { Limited funding for experimental materials and transport for field visits; difficulty in } \\
\text { transporting big classes to the field }\end{array}$ \\
It is time consuming; limited articulation skills among some students; difficult to \\
find local example for case study.
\end{tabular}

There is great awareness of and urge to apply student-centered learning approaches but there are challenges responsible for the limited use of the same. In the findings, there are structural, programming, student abilities and attitudes, lecturers' capacities and institutional factors limiting application of the different experiential learning approaches at SAS as enumerated in Table 4. Research by Baeten et al. (2010) states that each approach is constrained by specific factors some outside the control of a lecturer, irrespective of their training. Short class periods, large class sizes and limited resources as reported by Wurdinger and Rudolf (2009) also apply to the SAS. The challenges may be heightened in the SAS due to limited efforts to fully institutionalize and plan for experiential learning approaches. This in effect contributes largely to the slow adoption and use of experiential learning approaches. From the findings, it is apparent that exposure to experiential learning approaches takes place through isolated project activities seldom integrated into the functioning of the SAS. Without institutional (structural and leadership) integration of experiential learning, Eyler (2009) cautions that without institutional structure and leadership, integration of experiential learning will remain remote to the common teaching practices making attainment of its promise difficult. A number of lecturers stated that the university should make attendance of pedagogical short courses a requirement for all beginning lecturers so that they are equipped with effective learner-centered approaches.

However, to apply the experiential learning approaches and make course content interesting to students with emphasis on practical learning (Svinvki and McKechie, 2011) calls for improvement in the teaching environment and capacity building. Some of the lecturers interviewed believed that: infrastructure set-up in lecture rooms should be modified; staff should continuously be trained on the experiential learning approaches and; experiential learning should be in integrated into the entire university education system. Whilst these are general and long term recommendations, there is also need for creativity among lecturers (Wurdinger and Rudolf, 2009) to try new things in and out of the classroom. Use of short practical/reflective episodes, small discussion groups and presentations and, trying simulation could partially address the challenges of time limitation, large classes and resource constraints, respectively. Curriculum, as well as institutional policies and structural review are necessary to make learning practical and interesting.

Based on the success of the Earth and Land Grant Universities models for experiential learning, more emphasis is placed on out of class practical training through university farms and continuous community engagement activities enable students to learn from encountering real community challenges. Damian et al. (2007.p.524), quoting Bailey (1905), caution academics of the use of farms as models where students only act as spectators and state that "if we learn plowing in the classroom, we must equally study in the farm... we must determine and test the relation of plowing with moisture, aeration, microbial life and many other questions". A university farm should be a major tool for experiential learning. In addition, dedicated, staffed and facilitated engagement units are established to manage experiential learning and engagement activities as a strong precedence for institutionalization of these practices. 


\section{Conclusion and Recommendation}

The study presents empirical evidence that training lecturers in experiential learning is important to the improved use of learner-centered teaching approaches in undergraduate programmes. Lecturers at SAS use a variety of teaching approaches that when used collectively, match the definition of experiential learning in tandem with the prepositions of the Experiential Learning Theory. However, the traditional lecture method remains the most used. Besides training, other policy and structural factors influence application of experiential learning approaches. The challenges of short class periods, large class sizes and financial limitations have constrained increased application of the more practical approaches that enhance critical and reflective thinking for the attainment of lifelong learning abilities. Efforts to promote experiential learning approaches are at project level and not institutionalized.

The findings suggest the need to address the constraints to improve the application of experiential learning approaches. Continuous building of the individual lecturers' capacity in basic pedagogy and adult learning concepts as well as embedding learning in personal practical actions for students is necessary. This will ensure that all lecturers are exposed to a deeper and common understanding of experiential learning approaches. Competences in participatory teaching approaches should be seen as a necessity for every lecturer at SAS. This can be done throughtraining of all lecturers and curriculum review to integrate experiential learning practices as part of the general teaching quality assurance measures. Increasing the use of the university farm and surrounding communities throughout the bachelors' degree programme will enhance exposure to practical experiential learning among students. The study is a pioneer effort to interrogate application of experiential learning approaches for training agricultural students in Makerere University. This should stimulate further research interest contribute to necessary knowledge for improving their integration in Makerere and other such universities.

\section{Acknowledgement}

The authors thank the College of Agricultural Sciences (CAES), Makerere University and the Regional Universities Forum for Capacity Building in Agriculture (RUFORUM) for their support of this work through the RU/CARP03: Strengthening University Farming Community Engagement (SUFACE) Project Grant.

\section{References}

Acayo, P.C. (2013). Design education for Ugandan Secondary Schools. Masters Degree Thesis. Kent State University. 111.

Arnold, N. \& Paulus, T. (2010). Using a social networking site for experiential learning: Appropriating, lurking, modeling and community building. Internet and Higher Education, 13, 188-196. https://doi.org/10.1016/j.iheduc.2010.04.002

Aspin, D.N., Chapman, J., Evans, K. \& Bagnall, R. (2012). Second International Handbook of Lifelong Learning. New York: Springer. https://doi.org/10.1007/978-94-007-2360-3

Austin, P.C. (2010). Statistical criteria for selecting the optimal number of untreated subjects matched to each treated subject when using many-to-one matching on the propensity score. American Journal of Epidemiology, 6. https://doi.org/10.1093/aje/

Baeten, M., Kyndt, E., Struyven, K. \& Dochy, F. (2010). Using student-centred learning environments to stimulate deep approaches to learning: Factors encouraging or discouraging their effectiveness. Educational Research Review. Article in Press, 18. https://doi.org/10.1016/j.edurev.2010.06.001

Barraket, J. (2007). Teaching research methods using student-centered approach? Critical reflections on practice. Journal of University Teaching and Learning Practice, 11.

Bartle, E. (2015). Experiential learning: An overview. A discussion paper prepared for the Vice Chancellors' Retreat, March $23^{\text {rd }}-24^{\text {th }}, 2015$. Institute for Teaching and Learning Innovation $8 \mathrm{pp}$.

Bloom, B.S., Hastings, J.T. \& Madaus, G.F. (1971), Handbook on Formative and Summative Evaluation of Student Learning, McGraw-Hill, New York, NY.

Caprara, G.V., Veechione, M., Alessandri, G., Gerbino, M. \& Barbaranelli, C. (2011). The contribution of personality traits and self-efficacy beliefs to academic achievement. A longitudinal study. British Journal of Education Psychology, 81, 78-96. https://doi.org/10.1348/2044-8279.002004

Damian, M.P., Cary, J.T., Navina, R.K. \& Bryce, T.B. (2007). Designing sustainable agriculture education: Academics' suggestions for an undergraduate curriculum at a land-grant university. Agriculture and Human Values, 24,523-533. https://doi.org/10.1007/s10460-007-9084-y 
Diseth, A., Pallesen, S., Brunborg, G. \& Larsen, S. (2010). Academic achievement among first semester undergraduate psychology students: The role of course experience, effort, motives and learning strategies. Higher Education, 59, 335-352. https://doi.org/10.1007/s10734-009-9251-8

Driscoll, B.A. (2011). Graduates' perspectives regarding the impact of the integration of experiential learning in academic programmes. Graduate Thesis and Dissertations. Iowa State University Paper 12116.

Eyler, J. (2009). The power of experiential education. Liberal Education, 24-32.

Ezati, B.A., Opolot, C.O. \& Ssentamu, P.N. (2014). Addressing Pedagogical Training Needs of Teaching Staff: Lessons from Makerere University Short Professional Development Programs 2006 - 2010. American Journal of Educational Research, 2(12), 1190-1198. https://doi.org/10.12691/education-2-12-9

Fry, H., Ketteridge, S. \& Marshall, S. (2009). A handbook of teaching and learning in graduate learning in higher education: Enhancing academic practice ( $3^{\text {rd }}$ ed.), New York, USA: Routledge.

Haak, D. C., HilleRisLambers, J., Pitre, E., \& Freeman, S. (2011). Increased structure and active learning reduce the achievement gap in introductory biology. Science, 332, 1213-1216. https://doi.org/10.1126/science. 1204820

Hawkins, R. \& Lopokoit, (2012). Short report on outreach experiential learning workshops, Makerere, Moi Universities, June 2012 (RH and ML, June 15, 2012

Hawkins, R. (2010). Experiential learning, action research and outreach: A gap analysis. Consultancy report for the project "Shifting from outreach to engagement: Transforming universities' response to current development trends in agricultural research and training in Eastern, Central and Southern Africa".

Justine, C., Rice, J., Warry, W., Inglis, S., Miller, S. \& Sammon, S. (2007). Inquiry into higher education: Reflections and directions on course design and teaching methods. Innov. High Educ., 31, 201-214. https://doi.org/10.1007/s10755-006-9021-9

Kibwika, P. (2006). Learning to make change. Developing innovation competence for recreating the African University of the $21^{\text {st }}$ Century. PhD Thesis, Wageningen.

Kember, D., Leung, D.Y.P. \& McNaught, C. (2008). A workshop activity to demonstrate that approaches to learning are influenced by the teaching and learning environment. Active Learning in Higher Education, 9, 43-56. https://doi.org/10.1177/1469787407086745

Kolb, D.D. (1984). Experiential learning: Experience as the source of learning and development. Prentice Hall, Inc. Englewood Cliffs, New Jersey.

MAK (Makerere University Kampala), (2014). Policy on promotion tracks for academic staff of Makerere University. Reviewed and approved by the University Council at the $131^{\text {st }}$ meeting of council meeting held on $9^{\text {th }}$ and $22^{\text {nd }}$ May, 2014. Pp13. www.policies.mak.ac.ug/.../policies/reviewed-policy-on-promotion-tracks

MAK (Makerere University Kampala), (2013). Directorate of Human Resources: Employment opportunities (Externa) Academic and Administrative Staff. http://mak.ac.ug/documents/HRD/2012/Mak-HRD-Academic-Staff-2012-CoNAS.pdf

MAK (Makerere University). (2012). Directorate of Human Resources: Employment opportunities. http://mak.ac.ug/sites/default/files/downloads/Makerere-Academic-Employment-Opportunities-July2013.pdf

MAK (Makerere University Kampala), (2006). Employment opportunities and performance of Makerere University graduates: A tracer study of graduates in the fields of agriculture and veterinary medicine (1991-2001) Final Report, $25^{\text {th }}$ September 2006.

Mugabi, H. (2015). Institutional commitment to community engagement: A case study of Makerere University. International Journal of Higher Education, 4(1), 187-199. https://doi.org/10.5430/ijhe.v4n1p187

Mugisha, J. \& Nkwasibwe, A. (2014). Capacity development for modernizing African Food Systems (MAFS).Tracer Study of Agricultural Graduates in Uganda. MAFS Working Paper, 6. 30.

NIU (Northern Illinois University). (2013). Experiential learning. Faculty Development and Design Centre, 815.753.0595.

Obaa, B.B. (2013). Shifting from outreach to engagement: Transforming universities' response to current development trends in agricultural research and training in Eastern, Central and Southern Africa. Final report of the second Makerere University experiential learning and action research workshop held at Imperial Botanical Beach Hotel, 4-8 March 2013. 
O’Neill, G. \& McMahon, T. (2005). Student-cantered learning: What does it mean for students and lecturers? In: Emerging Issues in the Practice of University Learning and Teaching. 27-35.

Owusu-Acheampong, E., Asamoah, A.W. \& Azu, T.D. (2014). Industrial Attachment: Perspectives, conceptions and misconceptions of students at Cape Coast Polytechnic, Ghana. Journal of Education and Practice, 5(37), 63-67.

Pantiru, S., Jolley, S. \& Barley, R. (2012). Strengths and limitations of a learner-centered approach to teaching research methods. Student Engagement and Experience Journal, 1(3), 1-15. https://doi.org/10.7190/seej.v1i3.54

Prince, J.M. \& Felder, R.M. (2006). Inductive teaching and learning methods: Definitions, comparisons and research bases. Journal of Engineering Education, 95, 123-138. https://doi.org/10.1002/j.2168-9830.2006.tb00884.x

Rolf, J. (2007). On Case Study Methodology. Open House International, 32(3), 46-54.

Slavich, M.G. \& Zimbardo, P.G. (2012). Transformational teaching: Theoretical underpinnings, basic principles and core methods. Educ. Psychol Rev. https://doi.org/10.1007/s10648-012-9199-6

Smits, E.J. \& Rossi, E. (2005). The binomial distribution and proportions. Seminar in Statistics and Methodology, 39.

Sunmonu, S.O. \& Tijani, O.M. (2013). Internship placement for accounting undergraduates in Nigeria: An empirical analysis of stakeholders' perspective. European Journal of Humanities and Social Sciences, 21(1), 1067-1085.

Svinivki, M. \& McKeachie, W.J. (2011). McKeachie's teaching tips: Strategies, research and theory for college and University Teachers. (Thirteenth Ed.). Wadsworth: Belmont, CA.

Twenge, J. M. (2009). Generational changes and their impact in the classroom: Teaching Generation Me. Medical Education, 43, 398-405. https://doi.org/10.1111/j.1365-2923.2009.03310.x

Ueckert, C., Adams, A. \& Lock, J. (2011). Redesigning a large-enrolment introductory biology course. CBE Life Sciences Education, 10, 164-174. https://doi.org/10.1187/cbe.10-10-0129

World Bank. (2012). Agricultural and Rural Innovation Systems: An Investment Sourcebook. Washington, DC.

Wurdinger, S. \& Rudolph, J. (2009). Teaching practices that improve student learning: Five experiential approaches. Journal of Teaching and Learning, 6(1), 1-13. https://doi.org/10.22329/jtl.v6i1.505

Yin, R. (2006). Case Study Research: Design and Methods. Applied Social Research Methods series, 5, 25. Sage Publications, Thousand Oaks, London.

YU (York University). (2013). A case for change: Experiential education integration at York University. Draft Discussion Paper. 26. 